\title{
Investigation and evaluation of key success factors in technological innovation development based on BWM
}

\author{
Sina Ghaffari ${ }^{a}$, Alireza Arab ${ }^{a^{*}}$, Javid Nafari ${ }^{\mathrm{b}}$ and Manuchehr Manteghic \\ a. Department of Management, University of Tehran, Tehran, Iran \\ ${ }^{b}$ Department of management, science, and technology, Amirkabir University of Technology, Tehran, Iran \\ ${ }^{c}$ Department of Industrial Engineering, College of Engineering, University of Tehran, Tehran, Iran

\section{A B S T R A C T}

\begin{tabular}{l}
\hline C H R O N I C L E \\
\hline Article history: \\
Received October 3, 2016 \\
Received in revised format: \\
October 22, 2016 \\
Accepted December 8, 2016 \\
Available online \\
December 92016 \\
\hline Keywords: \\
Technological innovation \\
development \\
MCDM \\
Best-worst method \\
Key success factors \\
Remotely-Piloted Helicopters \\
(RPH) industry
\end{tabular}

\begin{abstract}
Developing innovation, based on knowledge and technology, as a driving force of the economy, is necessary for survival and is required in having strong interactions within the globalized world of business. Innovation and technology development require an intertwined network of organizational interactions between public and private sector. The activities and interactions of these firms are the reasons for innovation development in the framework of innovation systems. Following strategies is of crucial necessity and importance in industries such as aerospace and remotely-piloted helicopters (RPH) with their complex characteristics, costly and time-consuming processes. Understanding the business environment and identifying the success factors is a significant step towards adopting innovative strategies and planning for technology development. The aim of this article is to evaluate the key success factors in technological innovation development of remotely-piloted helicopters (RPH) industry. The methodology used in this article is Best-Worst method which is considered as one of the most prominent and effective MCDM methods. Based on a case study and by reviewing the extant and relevant literature, the key success factors of technological innovation development of remotely-piloted helicopters (RPH) industry in Iran were identified. Then by applying the "Best-Worst" method and the experts' opinions, the key success factors were analyzed and prioritized. Finally, some suggestions are made by considering the results of the study.
\end{abstract}

(C) 2017 Growing Science Ltd. All rights reserved.

\section{Introduction}

The term "innovation" commonly refers to the introduction of a new idea, device or method. According to Drucker (2014), from a management perspective, "innovation" is "a change that creates a new dimension of performance" and according to the U.K Department of Trade, from an institutional perspective, it is the successful implementation of new ideas. In a forever changing environment, institutions can accord to their environment more easily through the flexibility offered by innovation

* Corresponding author. Tel. +98 9112599003

E-mail address: alireza.arab@ut.ac.ir (A. Arab)

(C) 2017 Growing Science Ltd. All rights reserved. doi: $10.5267 /$ j.dsl.2016.12.001 
(Hesselbein et al., 2002). "Innovativeness" is most commonly used as a scale to measure the degree of "newness" of an innovation. Products with a high degree of newness are seen as "highly innovative" and at the other end of the spectrum, they are considered as "low innovative" ones. The term "technological innovation" is defined through identification of innovation types. Distinctive definitions of innovation are found in economics, management, marketing and engineering (Garcia \& Calantone, 2002). Processes of technological innovation are not made up of certain steps but rather they are exploited and utilized through complex adaptive systems of interrelated actors including institutions ranging from local to global. Obstructions emerge through all stages of innovations, from the invention of technology through its retirement. Economic growth and enhanced human welfare are some of the important societal objectives that have been achieved through technological innovation. However, innovation systems which are essentially directed by market forces and highly resourced actors, are denoted by extensive power disparities (Anadon et al., 2016). A foresight study was conducted on 5 prioritized industries, including aerospace, with the help of 200 experts in Iran's Science Policy Organization. The results of the study clarified that development of remotely-piloted helicopters (RPH) industry is the second priority and the production of remotely-piloted helicopters is the third important strategic objective based on the experts' opinions. The application of strategic management in order to coordinate the plans and objectives with the conditions of the business environment is of critical importance to any organization and industry, and the remotely-piloted helicopters (RPH) and aerospace industries, with their complex characteristics, costly and time-consuming processes, are no exception. The success factors in technological innovation development all have varying weights. In other words, different weights should be applied based on each factor's condition and context. Therefore, Multiple Criteria Decision Making (MCDM) methods should be used to incorporate different contributing criteria. The aim of this research is to propose a model for prioritization of key success factors in technological innovation development in Iran's remotely-piloted helicopters (RPH) industry, using one of the most novel MCDM techniques called Best-Worst method. Most previous research have studied key success factors of innovation at the firm level, whereas in this study the researchers aim to study the key success factors comprehensively from the broader perspective of the industry. Moreover, applying one of the most novel methods in decision making is another highlight of this article.

The rest of this article is categorized as follows. Section 2 is dedicated to the review of prior research regarding key success factors of innovation development. Section 3 presents the methodology of this research and BWM. Section 4 illustrates the application of proposed framework by a case study. Section 5 presents and discusses the results and the subsequent implications.

\section{Literature review}

Successful implementation and commercialization of disruptive innovations is not only achieved through the firm's conceptualization and development of innovation but also through its success in reaching more than a niche market of innovators-early adopters. To put it another way, it must cross the chasm and also conquer the innovator's dilemma (Slater \& Mohr, 2006). In new product development literature, an excessive number of definitions for types of innovation has created ambiguity in the operationalization and utilization of such terms as "innovation" and "innovativeness". The terms which are prevalently used in identifying innovations are "radical", "really new", "incremental" and "discontinuous" (Garcia \& Calantone, 2002). The fact that product development projects deal with innovation makes the chances of achieving success slim. The risks involved with product development projects are identified as technical, market and financial risks. A senior product development manager must make decisions in an environment where these uncertainties exist. Therefore, project success is achieved by acquiring adequate knowledge and information before and during a new product development project (Chang, 2012). Research has shown that each of the success factors cannot guarantee positive outcomes individually and that a combination of them is needed to achieve success (Cooper \& Kleinschmidt, 2007). Systemic instruments are perceived as novel ways to carry out change processes and trigger sustainability-oriented technological innovation (Smits \& 
Kuhlmann, 2004; Raven et al., 2010; Voß et al., 2009; van Mierlo et al., 2010). The focus of functional analysis is on the processes that are of necessity to the effective performance of innovation systems. These processes are classified according to the functions of innovation systems. Moreover, they help to elucidate the dynamics of innovation systems. (Johnson, 2001; Bergek, 2002; Hekkert et al., 2007; Bergek et al., 2008). The review of the literature to find and analyze key success factors in technological innovation development resulted in a comprehensive list of key success factors shown in Table 1.

\section{Table 1}

Key success factors in technological innovation development

\begin{tabular}{|c|c|c|}
\hline Criteria & Sub-criteria & References \\
\hline \multirow{9}{*}{$\begin{array}{l}\text { Factors associated with } \\
\text { actors and networks (K1) }\end{array}$} & Existence of Venture Capitals (K11) & \multirow{9}{*}{$\begin{array}{l}\text { Birchall (1996); Le Blanc (1997); } \\
\text { Khalil (2000); Porter (2000); Furman } \\
\text { (2002); Afuah (2003); Warren (2004); } \\
\text { Korea Technology and Information } \\
\text { Promotion Agency for SMEs (2006) }\end{array}$} \\
\hline & Clear definition of projects and user requirements (K12) & \\
\hline & $\begin{array}{l}\text { University Systems: Goal oriented and professional competitions, } \\
\text { Supporting the commercialization of the best participants (holding } \\
\text { university competitions with the participation of professionals in business } \\
\text { and hobby domains) (K13) }\end{array}$ & \\
\hline & $\begin{array}{l}\text { Implementing cooperation, networking mechanisms and creating } \\
\text { communication channels among research firms, suppliers, and users (K14) }\end{array}$ & \\
\hline & $\begin{array}{l}\text { Training of specialists at the University and vocational training and } \\
\text { research in the field of remotely-piloted helicopters (RPH) (K15) }\end{array}$ & \\
\hline & Existence of incubators and science and technology parks (K16) & \\
\hline & $\begin{array}{l}\text { Existence of Networks specialized in the remotely-piloted systems } \\
\text { (Including composites, engine, image processing, command, and control, } \\
\text { etc.) (K17) }\end{array}$ & \\
\hline & $\begin{array}{l}\text { The existence of professional forums for experts and elites in business and } \\
\text { hobby sectors (communication networks to organize and lead experts' } \\
\text { potentials towards industry) (K18) }\end{array}$ & \\
\hline & $\begin{array}{l}\text { International relations with professional and experts of RPH industry } \\
\text { (K19) }\end{array}$ & \\
\hline \multirow{7}{*}{$\begin{array}{l}\text { Factors associated with } \\
\text { Institutions (K2) }\end{array}$} & $\begin{array}{l}\text { Dedicated implementation of supportive policies and guidelines (including } \\
\text { related tax exemptions) (K21) }\end{array}$ & \multirow{7}{*}{$\begin{array}{l}\text { Khalil (2000); Afuah (2003); Ritter } \\
\text { (2003); Korea Technology and } \\
\text { Information Promotion Agency for } \\
\text { SMEs (2006) }\end{array}$} \\
\hline & $\begin{array}{l}\text { Implementation of juridical and security measures for flights over city } \\
\text { areas (civilian usage) (including laws regarding safety, environment, } \\
\text { accidents, social and cultural matters etc.) (K22) }\end{array}$ & \\
\hline & Intellectual property system (K23) & \\
\hline & $\begin{array}{l}\text { Implementation of rules, requirements, standards, licenses regarding RPH } \\
\text { (including specifying the differences and overlaps with manned aerial } \\
\text { vehicles fly zones) (K24) }\end{array}$ & \\
\hline & $\begin{array}{l}\text { Determining the technological strategy RPH sector (clarification and } \\
\text { sharing of industry and firms' responsibilities towards specialization and } \\
\text { also prevention of aimless parallel activities, correctly defining innovation } \\
\text { projects) (K25) }\end{array}$ & \\
\hline & $\begin{array}{l}\text { Determining the reference for technology policy adoption in RPH sector } \\
\text { (K26) }\end{array}$ & \\
\hline & $\begin{array}{l}\text { The government's careful and dedicated support of technology } \\
\text { development (New Technology Development Fund) in RPH sector (K27) }\end{array}$ & \\
\hline \multirow{5}{*}{$\begin{array}{c}\text { Factors associated with } \\
\text { Science and technology (K3) }\end{array}$} & $\begin{array}{l}\text { Implementation of interactive learning mechanisms among firms, } \\
\text { suppliers and users (to enhance technological capabilities at the national } \\
\text { level) (K31) }\end{array}$ & \multirow{5}{*}{$\begin{array}{l}\text { Porter (2000); Furman (2002); Afuah } \\
\text { (2003); Wirawan (2012) }\end{array}$} \\
\hline & Scientific and professional journals and publications (K32) & \\
\hline & Basic Research (K33) & \\
\hline & $\begin{array}{l}\text { Existence of specialized research laboratories for different sub-sectors of } \\
\text { RPH industry (also making sure that these laboratories are available to the } \\
\text { industry actors) (K34) }\end{array}$ & \\
\hline & $\begin{array}{l}\text { Documentation of the obtained knowledge and experience regarding past } \\
\text { innovation development projects and the reasons for their failures } \\
\text { (documentation of various experiences in the country's specialized sectors } \\
\text { of RPH industry including composites, image processing, design and } \\
\text { production of on ground stations) (K35) }\end{array}$ & \\
\hline
\end{tabular}

Schilling (1967) was the first one to introduce the term "key success and failure factors". He studied the role of project managers' experiences in project success or failure. Some researchers accentuated the importance of organizational structure (Petersen \& Malone, 1975). Pinto and Covin (1989) realized that the project team and project matrix are among the most effective organizational structures. Pinto and Covin (1989) asserted that the sector in which the project is set-up impacts the success factors of the project. Belassi and Tukel (1996) pointed to the effect of external factors like political, economic, social and sectorial factors. Parry and Song (1994) studied these effects in China and Canada. The results 
indicated that competitiveness could provide a serious obstacle to innovation success in China whereas this was not the case in Canada. Contrary to Canadian firms, Chinese firms place great emphasis on the beginning stages of the process namely market research. In China, innovations arising from the market have more chances of success than innovations emerging from technical work. Xin et al. (2004) categorized the success factors into strategic (including project's mission, the executive's support and appropriate scheduling) and technical (consultation with the employer, selection and training of personnel), and in their future studies asserted that the importance and relevance of each of these factors varies depending on project life cycle. Numerous studies have examined the effects of environmental conditions on the success of innovation projects in various countries (Xin et al., 2004). Calantone et al. (1996) studied 142 new product development projects in U.S.A and China and found some differences. They reported that resources and marketing skills were of significant importance to innovation development success in China. There were also other studies which were conducted in developed countries (i.e. Cooper, 1979). These studies all emphasized that success factors are influenced by industry, economic development, firm size and environmental circumstances and that there is no universal blueprint for achieving success (Xin et al., 2004). Furman (2002) stated that R\&D in universities, the strength of venture capitals, strong local competition, local suppliers and related firms' capabilities are factors contributing to the effective development of innovation.

\section{Research Methodology}

In this section, a novel MCDM model based on BWM is presented to address the problem of investigation and evaluation of Key Success Factors in Technological Innovation Development. This research is applied in terms of goal and descriptive and survey in terms of data collection since it tries to identify and describe the Key Success Factors in Technological Innovation Development. The flowchart of the proposed MCDM approach is shown in Fig. 1.

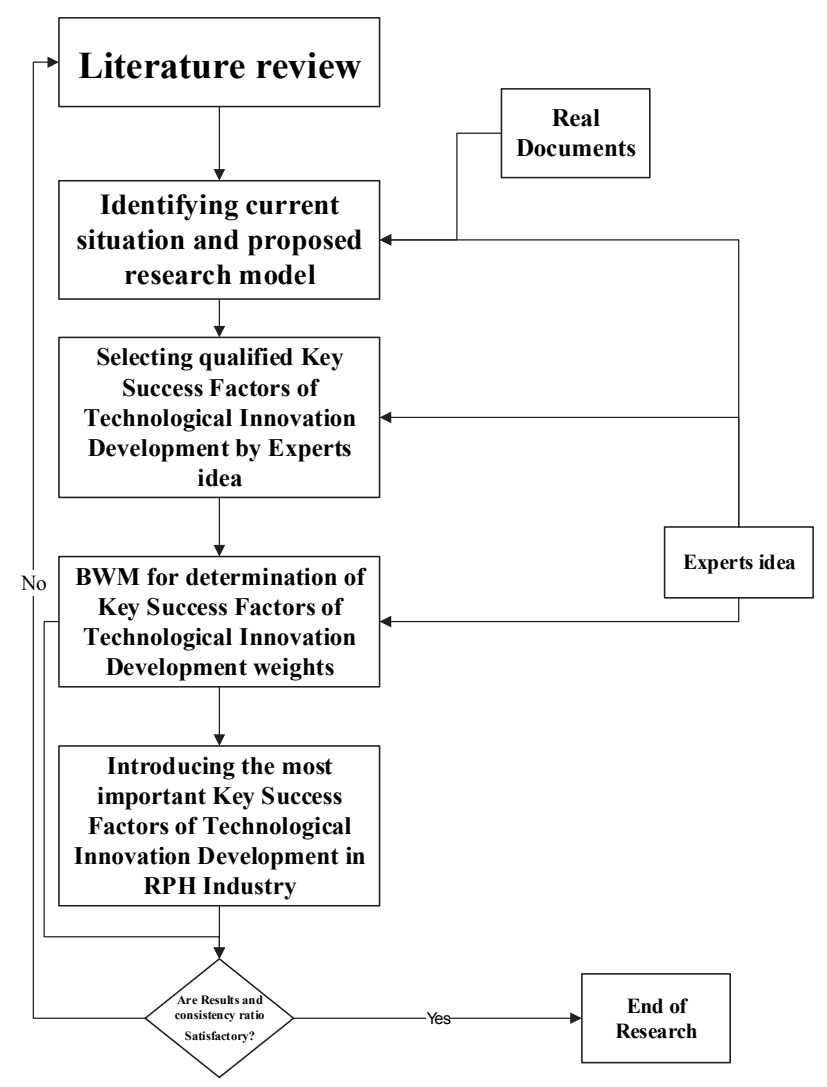

Fig. 1. Flowchart of the proposed MCDM approach 
In the present research documentary method (books, articles, and online texts) were used to identify the key factors. By using field study method, questionnaires were distributed among specialists and experts of the Iran's Remotely-Piloted Helicopters (RPH) industry (5 experts including CEO, Vice President of Research and technology, and R\&D manager of Iran Aviation Industries Organization (IAIO), a faculty member of Allameh Tabataba'i University, and a professor in Islamic Azad University Science and Research Branch) to prioritize the factors. In order to demonstrate the efficiency of the research approach, a case study of Iran's Remotely-Piloted Helicopters (RPH) industry is presented.

\subsection{The Best Worst Method}

BWM is a Comparison-Oriented MCDM method that compares the best criterion to the other criteria and all the other criteria to the worst criterion. The goal is to find the optimal weights and consistency ratio through a simple linear optimization model constructed by the comparison system (Rezaei et al., 2016b). In the literature, some papers have utilized this novel MCDM approach.

Below is a description of the steps of BWM to calculate the weight of the criteria (Rezaei, 2015a; Rezaei et al., 2015b):

1) Determine the set of decision criteria $\left\{c_{1}, c_{2}, \ldots, c_{n}\right\}$ by decision-makers.

2) Determine the best and the worst criteria to be used for the decision environment:

In this step, decision makers choose the best and the worst criteria among the set of criteria identified in Step 1 from their perspective. The best criteria represent the most important criteria and the worst criteria are the least important criteria for the decision.

3) Determine the preference of the best criteria over all the other criteria:

A number between 1 and 9 (1: equally important, 9: extremely more important) is used to indicate this value. The resulting Best-to-Others vector would be as $A_{B}=\left(a_{B 1}, a_{B 2}, \ldots, a_{B n}\right)$. Where $a_{B \mathrm{j}}$ indicates the preference of criteria B (best criteria) over criteria $\mathrm{j}$ and $a_{B \mathrm{~B}}=1$.

4) Determine the preference of each of the other criteria over the worst criteria:

A number between 1 and 9 is assigned to this case as well. The Others-to-Worst vector would be as $A_{W}=\left(a_{1 W}, a_{2 W}, \ldots, a_{n W}\right)^{T}$. Where, $a_{\mathrm{j} W}$ indicates the preference of the criteria $\mathrm{j}$ over the worst criteria $\mathrm{W}$ and $a_{\mathrm{W} W}=1$.

5) Find the optimal weights $\left(w_{1}^{*}, w_{2}^{*}, \ldots, w_{n}^{*}\right)$ :

Solving problem (1) will result in the optimal weights for the criteria. To determine the optimal weights of the criteria, the maximum absolute differences $\left\{\left|w_{B}-a_{B j} w_{j}\right|,\left|w_{j}-a_{j w} w_{w}\right|\right\}$ for all j should be minimized.

$$
\begin{aligned}
& \min _{\max _{j}}\left\{\left|\frac{w_{B}}{w_{j}}-a_{B j}\right|,\left|\frac{w_{j}}{w_{w}}-a_{j w}\right|\right\} \\
& \sum_{j}^{\text {s.t. }} w_{j}=1 \\
& w_{j} \geq 0, \text { for all } j
\end{aligned}
$$

This model can be solved by transferring it to the linear programming formulation (2) (Rezaei, 2015b): 


$$
\begin{aligned}
& 300 \\
& \min \xi \\
& \text { s.t. } \\
& \left|w_{B}-a_{B j} w_{j}\right| \leq \xi, \text { for all } j \\
& \left|w_{j}-a_{j w} w_{w}\right| \leq \xi, \text { for all } j \\
& \sum_{j} w_{j}=1 \\
& w_{j} \geq 0, \text { for all } j
\end{aligned}
$$

By solving this problem the optimal weights $\left(w_{1}^{*}, w_{2}^{*}, \ldots, w_{n}^{*}\right)$ and the optimal value of $\xi^{*}$ are obtained. $\xi^{*}$ is defined as the consistency ratio of the comparison system. It means that the closer $\xi^{*}$ is to a zero value the more consistent the comparison system provided by the decision makers. Eq. (3) is used to check the consistency of the comparisons (Rezaei et al., 2016a):

$$
\text { Consistency Ratio }=\frac{\xi^{*}}{\text { Consistency Index }}
$$

The consistency index can be retrieved from Table 2. The lower the consistency ratio, the higher the reliability of the comparisons.

Table 2

Consistency index table (Rezaei, 2015a)

\begin{tabular}{clllllllll}
\hline$a_{B W}$ & 1 & 2 & 3 & 4 & 5 & 6 & 7 & 8 & 9 \\
\hline Consistency index & 0.00 & 0.44 & 1.00 & 1.63 & 2.30 & 3.00 & 3.73 & 4.47 & 5.23 \\
\hline
\end{tabular}

\section{Empirical Example}

At this step, BWM which was explained in section 3 is utilized to obtain importance weights of technological innovation development key success factors.

\section{Determination of the criteria set}

The criteria set is determined on the basis of the extensive literature review and interview with research experts as shown in the table (1).

\section{Determination of the best and the worst criterion}

The second step in the BWM is the determination of the best and the worst criterion. The best criterion is the one selected by each respondent as the most important key success factor for technological innovation development, while the worst criterion is the one which is the least important key success factor for technological innovation development based on the opinion of each expert. Experts of this research selected factors associated with actors and networks (K1) as the best criterion and factors associated with Institutions (K2) as the worst criterion. Also experts in this research selected clear definition of projects and user requirements (K12) and existence of professional forums for experts and elites in business and hobby sectors (K18) in factors associated with actors and networks, the government's careful and dedicated support of technology development (New Technology Development Fund) in RPH sector (K27) and intellectual property system (K23) in factors associated with institutions, documentation of the obtained knowledge and experience regarding past innovation development projects and the reasons for their failures (K35) and scientific and professional journals and publications (K32) in factors associated with science and technology as the best and worst subcriteria respectively. 


\section{Determination of the preference of the best criterion over all others}

This step consists of identifying preferences of the best criterion over all others criteria. This data is gained by using BWM special questionnaire. The experts are asked to compare their selected best criterion to each of the other criteria and state their preference by using a value from 1 to 9 . A score of 1 implies an equal importance over the other criteria. A score of 9 implies the most important criterion is extremely more preferred to the other criteria. Then by calculating the arithmetic mean of the five experts' questionnaires, aggregated Best-to-Others (BO) vector was constructed, which illustrated in Table 3. Also sub- criteria aggregated Best-to-Others (BO) vectors are shown in Tables (4-6).

\section{Table 3}

Criteria BO Vector

\begin{tabular}{llll}
\hline Best criterion & $\mathrm{K} 1$ & $\mathrm{~K} 2$ & $\mathrm{~K} 3$ \\
$\mathrm{~K} 1$ & 1 & 2.8 & 1.8 \\
\hline
\end{tabular}

\section{Table 4}

Actors and Networks sub-criteria BO Vector

\begin{tabular}{lccccccccc}
\hline Best criterion & K11 & K12 & K13 & K14 & K15 & K16 & K17 & K18 & K19 \\
\hline K12 & 7.8 & 1 & 4.8 & 2.8 & 3.8 & 6.8 & 2.2 & 8.8 & 6.2 \\
\hline
\end{tabular}

\section{Table 5}

Institutions sub-criteria BO Vector

\begin{tabular}{llllllll}
\hline Best criterion & K21 & K22 & K23 & K24 & K25 & K26 & K27 \\
\hline K27 & 4.8 & 6.8 & 9 & 5.8 & 2.2 & 3.8 & 1 \\
\hline
\end{tabular}

\section{Table 6}

Science and technology sub-criteria BO Vector

\begin{tabular}{llllll}
\hline Best criterion & K31 & K32 & K33 & K34 & K35 \\
\hline K35 & 4.8 & 9 & 6.8 & 2.8 & 1 \\
\hline
\end{tabular}

\section{Determination of the preference of all criteria over the worst criterion}

This step is similar to the previous step, but in this step, the experts are asked to state their preferences of all other criteria over the least important criterion. Similar to the previous step, a value from 1 and 9 is used. Then by calculating the arithmetic mean of the five experts' questionnaires, aggregated Othersto-Worst $(\mathrm{OW})$ vector was constructed, which is illustrated in Table 7. Also, sub-criteria aggregated Others-to-Worst (OW) vectors are shown in Tables (8-10).

Table 7

Criteria OW Vector

\begin{tabular}{ll}
\hline Worst criterion & K2 \\
\hline K1 & 2.8 \\
K2 & 1 \\
K3 & 1.2 \\
\hline
\end{tabular}

\section{Table 8}

Actors and Networks sub-criteria OW Vector

\begin{tabular}{ll}
\hline Worst criterion & K18 \\
\hline K11 & 2.2 \\
K12 & 8.8 \\
K13 & 4.8 \\
K14 & 6.8 \\
K15 & 5.8 \\
K16 & 2.8 \\
K17 & 7.8 \\
K18 & 1 \\
K19 & 3.8 \\
\hline
\end{tabular}


Table 9

Institutions sub-criteria OW Vector

\begin{tabular}{ll}
\hline Worst criterion & K23 \\
\hline K21 & 3.8 \\
K22 & 2.2 \\
K23 & 1 \\
K24 & 2.8 \\
K25 & 7.8 \\
K26 & 5.8 \\
K27 & 9 \\
\hline
\end{tabular}

Table 10

Science and technology sub-criteria OW Vector

\begin{tabular}{ll}
\hline Worst criterion & K32 \\
\hline K31 & 4.8 \\
K32 & 1 \\
K33 & 2.8 \\
K34 & 7.2 \\
K35 & 9 \\
\hline
\end{tabular}

\section{Determination of the Technological Innovation Development Key Success Factors Weights}

The weights of technological innovation development key success factors are calculated with a linear model (2) of BWM. By solving this linear model, optimized values of criteria and sub-criteria weights and $\xi^{*}$ can be obtained. The results are shown in Table 11.

Table 11

Technological innovation development key success factors weights

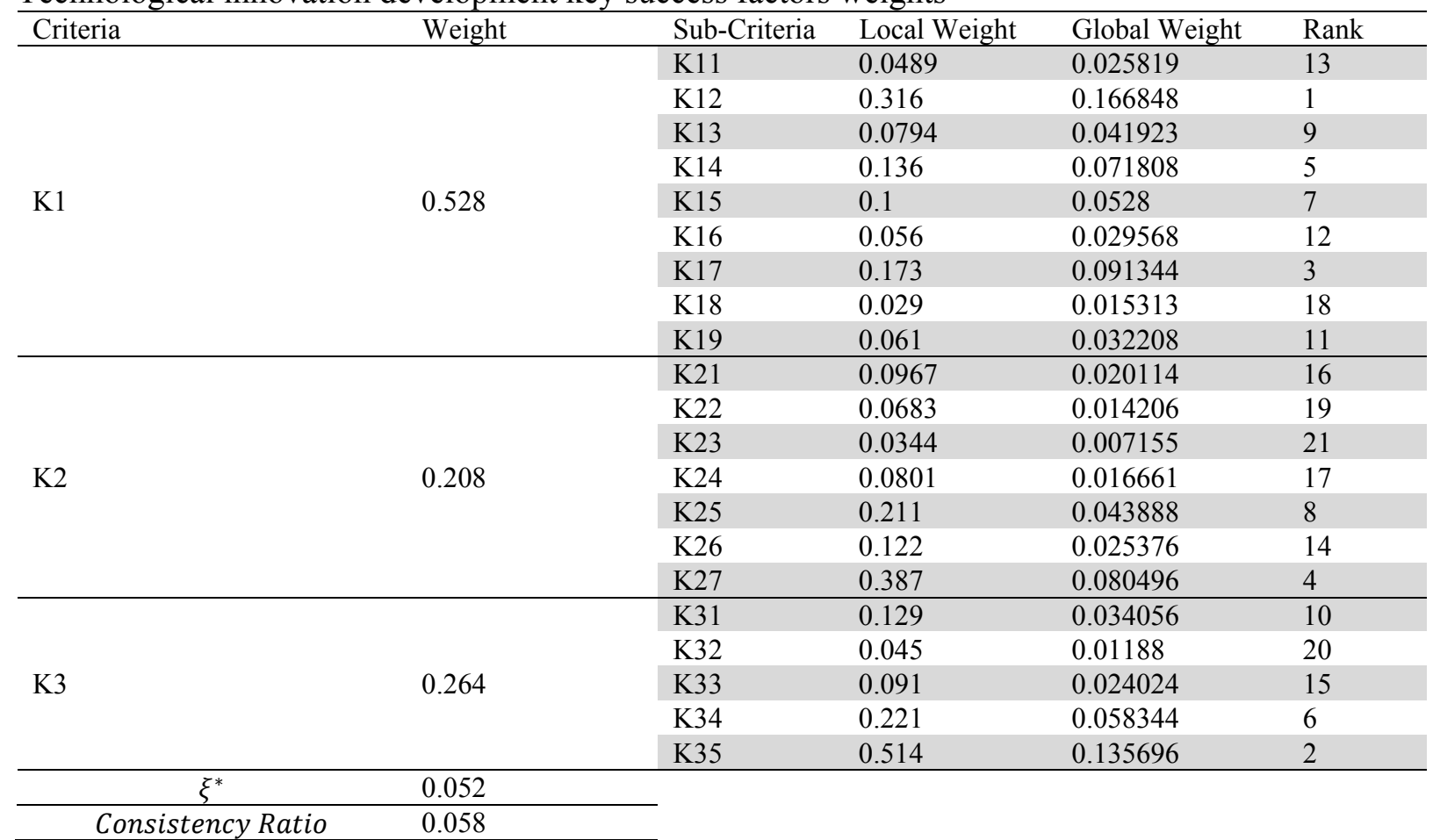

As can be seen from this results, in this case, 'factors associated with actors and networks (K1)', 'factors associated with science and technology (K3)' and 'factors associated with institutions (K2)' are the most important technological innovation development key success factors criteria respectively. Also 
'clear definition of projects and user requirements (K12)', 'documentation of the obtained knowledge and experience regarding past innovation development projects and the reasons for their failures (K35)' and 'existence of networks specialized in the remotely-piloted systems (K17)' are the most important technological innovation development key success factors sub-criteria and, 'intellectual property system (K23)', 'scientific and professional journals and publications (K32)' and 'implementation of juridical and security measures for flights over city areas (K22)' are the least important technological innovation development key success factors' sub-criteria respectively. Furthermore, 'clear definition of projects and user requirements (K12)', 'existence of networks specialized in the remotely-piloted systems (K17)' and 'implementing cooperation, networking mechanisms and creating communication channels among research firms, suppliers, and users (K14)' are the most important actors and networks sub-criteria. 'The government's careful and dedicated support of technology development (New Technology Development Fund) in RPH sector (K27)', 'determining the technological strategy in remotely-piloted helicopters (RPH) sector (K25)' and 'determining the reference of technology policy adoption in RPH sector (K26)' are the most important institutions sub-criteria and ' documentation of the obtained knowledge and experience regarding past innovation development projects and the reasons for their failures (K35)', 'existence of specialized research laboratories for different sub-sectors of RPH industry (K34)' and 'implementing cooperation, networking mechanisms and implementation of interactive learning mechanisms among firms, suppliers and users (K31)' are the most important science and technology sub-criteria. As shown in table 11, the comparisons show a very high consistency as the value of consistency ratio of criteria and sub-criteria is close to zero (the consistency ratio for criteria and sub-criteria comparisons were $0.058,0.012,0.014$ and 0.02 respectively).

\section{Discussion and conclusion}

Since Iran is in the last steps of its "1404 strategic plan", it has shifted the focus of its economy towards knowledge and technology. Innovation plays the most contributing economic role and the innovative RPH industry has a significant impact on the country's route to achieve its objectives. Identification and analysis of key success factors in technological innovation development is of considerable help in resolving existing problems and building a dynamic and effective sectorial system of innovation.

This article proposed a definite framework for identification of key success factors in technological innovation development of Iran's RPH industry. Considering the existing dearth of financing and the time restraint in achieving success in RPH industry, the key factors have been prioritized so that more focus will be placed upon the more important ones. In this article, the key success factors in RPH industry were identified and grouped into 3 categories with 21 factors then, according to experts' opinions answers and by applying the Best-Worst method, the identified factors were prioritized. The results indicate that factors associated with actors and networks, factors associated with science and technology and factors associated with institutions were the most important key success factors in technological innovation development in the RPH industry. Moreover, clear definition of projects and user requirements (K12), documentation of the obtained knowledge and experience regarding past innovation development projects and the reasons for their failures (K35), existence of networks specialized in the remotely-piloted systems (K17), government's careful and dedicated support of technology development (K27), implementing cooperation, networking mechanisms and creating communication channels among research firms, suppliers and users (K14) were the most important success factors respectively. Ultimately, some recommendations for further exploitation of the results are made. The researchers' recommendations are as follows:

\subsection{Recommendations for factors associated with actors and networks}

The factors are introduced to indicate that in this emergent industry in Iran the problem does not reside in shortage or non-existence of actors rather the quality, quantity and depth of interactions and relations which must exist among the actors to facilitate the innovation development process. Considering the 
novelty of RPH industry in Iran, this can be achieved through policy establishment regarding networking and relationship building among manufacturing and research firms, suppliers and customers. Moreover, correctly defining the requirements and their congruence with exiting collaboration capabilities among manufacturing and research firms, suppliers and customers is of great importance.

\subsection{Recommendations for factors associated with institutions}

Here, the major issue is not project financing rather correctly guiding the financial resources of the government towards innovation development. Therefore, the establishment of a comprehensive system of project performance appraisal and defining crucial decision-making points for continuing or discontinuing the project is an important and necessary step.

\subsection{Recommendations for factors associated with science and technology}

There exist various incomplete or half-finished projects in RPH industry in Iran. A systematic database of these past experiences can help future projects and teams in avoiding failure. Since the majority of the industry's focus is on defense, it is, therefore, necessary that one of the research organizations, with the support of senior managers, accepts the responsibility of systematic documentation of past projects' experiences.

The recommendations for further research are as follows:

- Studying the status quo of prioritized factors among firms and organizations of RPH sector in order to analyze the existing gaps.

- Inspecting the strategies of innovation development, by the government, as the most important and the strongest source of policy.

- Exploiting other methods of MCDM in identifying and prioritizing the key success factors.

- Analyzing the data through fuzzy sets theory in order to avoid or reduce the uncertainties and ambiguities surrounding these kinds of research.

- Exploring the obstacles of innovation development and creativity in RPH sector and comparing the results to the current research.

- Conducting a similar study in other sectors of aerospace industry.

- Examining the results of the current study in other sectors of aerospace industry.

\section{References}

Afuah, A. (2003). Innovation management: strategies, implementation and profits. Oxford University Press, USA.

Anadon, L. D., Chan, G., Harley, A. G., Matus, K., Moon, S., Murthy, S. L., \& Clark, W. C. (2016). Making technological innovation work for sustainable development. Proceedings of the National Academy of Sciences, 113(35), 9682-9690.

Belassi, W., \& Tukel, O.I. (1996). A new framework for determining critical success/failure factors in project. International Journal of Project Management, 14(3), 141-51.

Bergek, A. (2002). Shaping and exploiting technological opportunities: the case of renewable energy technology in Sweden. Göteborg: Chalmers University of Technology.

Bergek, A., Jacobsson, S., Carlsson, B., Lindmark, S., \& Rickne, A. (2008). Analyzing the functional dynamics of technological innovation systems: A scheme of analysis. Research policy, 37(3), 407-429.

Birchall, D. W., Chanaron, J. J., \& Soderquist, K. (1996). Managing innovation in SMEs: a comparison of companies in the UK, France and Portugal. International Journal of Technology Management, 12(3), 291-305.

Calantone, R. J., Schmidt, J. B., \& Song, X. M. (1996). Controllable factors of new product success: A cross-national comparison. Marketing Science, 15(4), 341-358. 
Chang, Y. C. (2012). How do established firms improve radical innovation performance? The organizational capabilities view. Technovation, 32(7), 441-451.

Cooper, R. G. (1979). Identifying industrial new product success: Project NewProd. Industrial Marketing Management, 8(2), 124-135.

Cooper, R. G., \& Kleinschmidt, E. J. (2007). Winning businesses in product development: The critical success factors. Research-Technology Management, 50(3), 52-66.

Drucker, P. (2014). Innovation and entrepreneurship. Routledge.

Furman, J. (2002). The determinants of national innovative capacity. Research Policy, 31(6), 899-933.

Garcia, R., \& Calantone, R. (2002). A critical look at technological innovation typology and innovativeness terminology: a literature review. Journal of Product Innovation mManagement, 19(2), 110-132.

Hekkert, M. P., Suurs, R. A., Negro, S. O., Kuhlmann, S., \& Smits, R. E. (2007). Functions of innovation systems: A new approach for analysing technological change. Technological Forecasting and Social Change, 74(4), 413-432.

Hesselbein, F., Goldsmith, M., \& Somerville, I. (2002). Leading for innovation and organizing for results. Jossey-Bass.

Johnson, A. (2001, June). Functions in innovation system approaches. In Nelson and Winter Conference, Aalborg, Denmark (pp. 12-15).

Khalil, T. M. (2000). Management of technology: The key to competitiveness and wealth creation. McGraw-Hill Science, Engineering \& Mathematics.

Korea Technology and Information Promotion Agency for SMEs (2006). A Reaserch on the innovation promoting policy for SMEs in APEC:survey and case studies, Seoul: Korea Technology and Information Promotion Agency for SMEs.

LeBlanc, L. J., Nash, R., Gallagher, D., Gonda, K., \& Kakizaki, F. (1997). A comparison of US and Japanese technology management and innovation. International Journal of Technology Management, 13(5-6), 601614.

Parry, M. E., \& Song, X. M. (1994). Identifying new product successes in China. Journal of Product Innovation Management, 11(1), 15-30.

Petersen, D. J., \& Malone, R. L. (1975). The personnel effectiveness grid (PEG): A new tool for estimating personnel department effectiveness. Human Resource Management (pre-1986), 14(4), 10.

Pinto, J.K., \& Covin J.G. (1989). Critical factors in project implementation a comparison of construction and R\&D projects. Technovation, 9, 49-62.

Porter, M. (2000). Competition and economic development: local clusters in global economy. Economic Development, 14.

Raven, R., Van den Bosch, S., \& Weterings, R. (2010). Transitions and strategic niche management: towards a competence kit for practitioners. International Journal of Technology Management, 51(1), 57-74.

Rezaei, J. (2015a). Best-worst multi-criteria decision-making method. Omega, 53, 49-57.

Rezaei, J. (2015b). Best-worst multi-criteria decision-making method: Some properties and a linear model. Omega, 64, 126-130.

Rezaei, J., Hemmes, A., \& Tavasszy, L. (2016a). Multi-criteria decision-making for complex bundling configurations in surface transportation of air freight. Journal of Air Transport Management.

Rezaei, J., Nispeling, T., Sarkis, J., \& Tavasszy, L. (2016b). A supplier selection life cycle approach integrating traditional and environmental criteria using the best worst method. Journal of Cleaner Production, 135, 577-588.

Rezaei, J., Wang, J., \& Tavasszy, L. (2015). Linking supplier development to supplier segmentation using Best Worst Method. Expert Systems with Applications, 42(23), 9152-9164.

Ritter, T., (2003). The impact of a company's business strategy on its technological competence, network competence and innovation success. Journal of Business Research, 57(5), 548-556.

Schilling, W. (1967). Recovery of the electrical resistivity of pure metals after short irradation with Neutrons inside a reactor. Zeitschrift-fuer-Angewandte-Physik, 22(6), 452-60.

Slater, S. F., \& Mohr, J. J. (2006). Successful development and commercialization of technological innovation: insights based on strategy type. Journal of Product Innovation Management, 23(1), 26-33.

Smits, R., \& Kuhlmann, S. (2004). The rise of systemic instruments in innovation policy. International Journal of Foresight and Innovation Policy, 1(1-2), 4-32. 
Van Mierlo, B., Leeuwis, C., Smits, R., \& Woolthuis, R. K. (2010). Learning towards system innovation: Evaluating a systemic instrument. Technological Forecasting and Social Change, 77(2), 318-334.

Voß, J. P., Smith, A., \& Grin, J. (2009). Designing long-term policy: rethinking transition management. Policy sciences, 42(4), 275-302.

Warren, M. (2004). A Study of Innovation:Anatomy of the Key Success Factors. Henley: Henley MBA dissertation,USA.

Wirawan, C. (2012). Open Innovation Implementation to Sustain Indonesian SMEs. Procedia Economics and Finance, 4(2), 223-233.

Xin, P.U., Jizhen, L.I., Zhu. H. (2004). cross-national study of success factors in innovation project: China and western developed countries. Research Center for Technological Innovation \& School of Economics and Management.

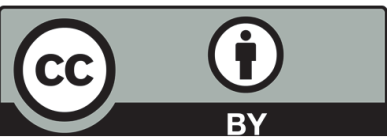

(C) 2017 by the authors; licensee Growing Science, Canada. This is an open access article distributed under the terms and conditions of the Creative Commons Attribution (CC-BY) license (http://creativecommons.org/licenses/by/4.0/). 